\title{
A Systematic Evaluation of Chip-Based Nanoelectrospray Parameters for Rapid Identification of Proteins from a Complex Mixture
}

\author{
Ana Gabriela Pereira-Medrano, ${ }^{\mathrm{a}}$ Alistair Sterling, ${ }^{\mathrm{b}, *}$ \\ Ambrosius P. L. Snijders, ${ }^{a}$ Kenneth F. Reardon, ${ }^{\mathrm{c}}$ and Phillip C. Wright ${ }^{\mathrm{a}}$ \\ ${ }^{a}$ Biological and Environmental Systems Group, Department of Chemical and Process Engineering, University \\ of Sheffield, Sheffield, United Kingdom \\ $\mathrm{b}$ Advion Biosciences, Norwich, United Kingdom \\ ${ }^{\mathrm{c}}$ Department of Chemical and Biological Engineering, Colorado State University, Fort Collins, CO, USA
}

HPLC-MS/MS is widely used for protein identification from gel spots and shotgun fractions. Although HPLC has well recognized benefits, this type of sample infusion also has some undesirable attributes: relatively low sample throughput, potential sample-to-sample carryover, time-varying sample composition, and no option for longer sample infusion for longer MS analyses. An automated chip-based ESI device (CB-ESI) has the potential to overcome these limitations. This report describes a systematic evaluation of the information-dependant acquisition (IDA) and sample preparation protocols for rapid protein identification from a complex mixture using a CB-ESI source compared with HPLC-ESI (gradient and isocratic elutions). Cytochrome $c$ and a six-protein mixture (11-117 kDa) were used to develop an IDA protocol for rapid protein identification and to evaluate the effects of sample preparation protocols. MS (1-10 s) and MS/MS (1-60 s) scan times, sample concentration (50-500 $\mathrm{fmol} / \mu \mathrm{L}$ ), and ZipTipC 18 cleanup were evaluated. Based on MOWSE scores, protein coverage, experimental run time, number of identified proteins, and reproducibility, a $12.5 \mathrm{~min}$ experiment (22 cycles, each with one $3 \mathrm{~s}$ MS and eight $10 \mathrm{~s}$ MS/MS scans) was determined to be the optimal IDA protocol for CB-ESI. This work flow yielded up to $220 \%$ greater peptide coverage compared with gradient HPLC-ESI and provided protein identifications with up to a 2-fold higher throughput rate than either HPLC-ESI approach, whilst employing half the amount of sample over the same time frame. The results from this study support the use of CB-ESI as a rapid alternative to the identification of protein mixtures. (J Am Soc Mass Spectrom 2007, 18, 1714-1725) (c) 2007 American Society for Mass Spectrometry

$\mathrm{T}$ The characterization of a proteome has evolved to a systematic identification and quantitation of proteins expressed in cells, usually with the aim to characterize all proteins expressed at a given time and in response to specific stimuli [1]. This is an extremely challenging endeavor, given the large numbers (thousands to tens of thousands, including variants due to post-translational modifications $[2,3])$, diversity, complexity, and concentration range of expressed proteins [4]. As a result, there is a need for rapid, low-cost, automated instrumentation capable of high detection sensitivity for low-abundance proteins and limited available sample quantity. Miniaturized proteomics analytical systems coupled with mass spectrometry have the potential to achieve these goals [5-9].

Address reprint requests to Professor P. C. Wright, Biological and Environmental Systems Group, Department of Chemical and Process Engineering, University of Sheffield, Mappin Street, Sheffield, S1 3JD, UK. E-mail: P.C.Wright@Sheffield.ac.uk

* Current address: Microsaic Systems, Surrey, UK.
Proteomics research is based on several technologies for protein/peptide fractionation before their identification and quantification using mass spectrometry [10-12]. Even with its acknowledged limitations, such as low throughput and poor resolution of very hydrophobic, extremely acid or basic, and large or small proteins $[13,14], 2 \mathrm{DE}$ remains the most popular technique, and is capable of resolving, with high quality, proteins from complex samples [15]. Alternatively, newer single and multidimensional shotgun fractionation techniques considerably improve the protein resolution, but may not provide sufficient improvements to the throughput rate, mostly due to the long gradient times when using highperformance liquid chromatography tandem mass spectrometry (HPLC-MS/MS) for the analysis of complex protein fractions. Examples of these techniques are MudPIT [16], HPLC/CE [17], liquid-phase IEF [18], gelphase IEF [19], IEF-IEF [20], and 1D PAGE-IEF-IEF [21].

Nanoelectrospray ionization (nanoESI), coupled to tandem mass spectrometry [22], is an important and 
widely used approach employed for large-scale protein identification, as it has the capability of generating high-quality peptide ion spectra $[12,23,24]$. NanoESI tandem MS employing HPLC (HPLC-ESI-MS/MS) has been shown to have high sensitivity for peptide identification, in the range of 5 to $10 \mathrm{fmol} / \mu \mathrm{L}$ for peptide mixtures, due to its capabilities to fractionate and concentrate peptide mixtures [25-28]. However, it has some disadvantages: (1) relatively low sample throughput, (2) potential sample-to-sample carryover, and (3) time-varying sample composition [9]. Several studies have evaluated the analytical properties of capillarybased nanoESI direct infusion sources, such as single protein identification of low sample concentrations after in-solution and in-gel digestion [22, 29], the benefits and limitations of sample cleanup using a reverse-phase matrix [22, 30], and the flow rate effect on analyte suppression [31]. One such report described the rapid (4 min) identification of proteins (single and three-protein mixture) using a nanoESI capillary for direct infusion, after in-solution and in-gel digestion, by evaluating total length of MS analysis, and comparing results obtained using nanoflow HPLC-ESI-MS/MS [32].

As new direct infusion devices, chip-based nanoESI (CB-ESI) analytical technologies have been developed in recent years [33-36]. One of these employs a siliconbased nanoelectrospray microchip [37] and, like other CB-ESI technologies, has potential advantages over HPLC-ESI, including higher-throughput, automated analysis with no carry-over [38], flexible MS acquisition time [9], and a constant sample matrix [9]. A limited number of investigations have indicated a set of preliminary performance parameters and limitations for this CB-ESI device. One previous study reported the successful identification of proteins in 2D gel spots from bacteria and yeast with a detection sensitivity of 50 pmol of myoglobin in solution and $150 \mathrm{fmol}$ of BSA loaded on gel [39]. A higher sequence coverage for BSA and a four-protein mixture (500 fmol each), shorter overall MS analysis time, and no need for spray optimization was achieved by CB-ESI-MS/MS analysis of capillary LC fractions collected off-line compared with HPLC-ESI-MS/MS [40, 41]. Unpublished results (described in reference [9]) showed an improvement in detection sensitivity of $75 \mathrm{fmol}$ of BSA loaded on-gel after a ZipTipC ${ }_{18}$ cleanup, indicating that sample handling and preparation before infusion are perhaps more important for CB-ESI than for a HPLC-ESI work flow. Wickremsinhe et al. [42] demonstrated ${ }^{\circ}$ the ${ }^{\circ}$ low $^{\circ}$ sample requirements and the absence of carryover compared with HPLC-ESI-MS/MS. To date, however, there have been no reports of a thorough evaluation on the effects of the major information-dependant acquisition (IDA) parameters used for rapid protein identification from a mixture employing a CB-ESI-MS/MS, considering the benefit of longer spraying times that allows for extended MS analyses.

In this study, we report the systematic evaluation and optimization of the IDA protocol (MS and MS/MS scan times) for the tandem MS detection of infused peptide complex mixtures from an automated CB-ESI device, as well as the evaluation of different sample preparation protocols (sample concentration and ZipTipC ${ }_{18}$ cleanup after in-gel tryptic digestion) for use with CB-ESI. The assessment of the capability and reproducibility of the CB-ESI device is also presented. Two standard tryptically digested samples were used in the assessment: (1) cytochrome $c$, to evaluate the identification of a single, small protein (11 KDa), and (2) a six-protein mixture, which included cytochrome $c$, to test the resolution capability for a range of protein sizes (11-135 KDa). The effects of the above factors on the MOWSE score and peptide coverage (at a fixed number of experimental cycles) are reported and compared with those obtained from isocratic and gradient HPLC-ESI-MS/MS work flows under exactly the same conditions. Furthermore, a thorough evaluation of the efficiency of the acquisition scans made in an experiment and the effects of different databases used for sequence searches in Mascot are investigated. A protocol is recommended that minimizes analysis time whilst maximizing peptide coverage and identification score for the CB-ESI system.

\section{Materials and Methods}

\section{Chemicals}

Trifluoroacetic acid (TFA) and methanol were purchased from Fisher Scientific (Loughborough, UK). Acetonitrile $(\mathrm{ACN})$, formic acid, and all other chemical reagents, unless otherwise noted, were obtained from Sigma-Aldrich (Gillingham, Dorset, UK). Sequencing grade-modified trypsin was from Promega (Southampton, UK). ZipTipC 18 tips were purchased from Millipore UK Ltd. (Watford, UK).

\section{Protein Samples}

Undigested cytochrome $c$ (equine heart) was purchased from Sigma for the in-gel digestion evaluation. Tryptically digested, lyophilized cytochrome $c$ and a sixprotein mixture were purchased from Dionex/LC Packings (Amsterdam, The Netherlands). The mixture consisted of: cytochrome c (11.68 kDa, A92022), lysozyme (14.77 kDa, A50971), alcohol dehydrogenase (ADH; 37.29 kDa, S57383), BSA (71.31 kDa, AF542068), apo-transferrin (79.91 kDa, U02564), and $\beta$-galactosidase (117.34 kDa, A92233). Protein digests were reconstituted according to the manufacturer's protocols. Aliquots of each standard were prepared and stored at $-20^{\circ} \mathrm{C}$. Samples were prepared at two different concentrations (50 and $500 \mathrm{fmol} / \mu \mathrm{L}$ of each protein) to evaluate the effect of concentration for the use of the CB-ESI-MS/MS and HPLC-ESI-MS/MS work flows. Samples analyzed by CB-ESI were diluted to the required concentration in $50 \%$ methanol and $0.1 \%$ formic acid; samples analyzed by HPLC-ESI were dried and re-dissolved to the re- 
quired concentration in a buffer consisting of $0.1 \%$ formic acid and 3\% ACN.

\section{Preparation of Tryptic Digests}

Cytochrome $c$ from horse heart was tryptically digested in-gel to compare the effect of protein in-gel digestion on the CB-ESI and HPLC-ESI sample introduction work flows; 1D SDS-PAGE was conducted on $7 \mu \mathrm{g}$ ( $565 \mathrm{pmol})$ of cytochrome $c$ loaded per well and the gel was stained with Bio-Safe Coomassie (Bio-Rad). Protein bands from each lane were excised such that all the visible protein was in the excised band, and thus it was assumed that the entire $565 \mathrm{pmol}$ of cytochrome $c$ was selected. All gel pieces were digested with modified trypsin after reduction $\left(10 \mathrm{mM}\right.$ DTT for $30 \mathrm{~min}$ at $\left.56^{\circ} \mathrm{C}\right)$ and alkylation (55 mM iodoacetamide and $50 \mathrm{mM}$ ammonium bicarbonate for $20 \mathrm{~min}$ in the dark at room temperature) of the proteins. Gel pieces were completely dried in a vacuum concentrator (Eppendorf AG, Cambridge, UK) before adding trypsin, assuming a 1:50 mass ratio (0.14 $\mu \mathrm{g}$ of trypsin). Trypsin was prepared according to the manufacturer's protocol. After overnight digestion at $37^{\circ} \mathrm{C}$ with no second addition of trypsin, the digested peptides were extracted. Dry digests were stored at $-20^{\circ} \mathrm{C}$. Before sample analysis via either the CB-ESI or HPLC-ESI work flow, samples were diluted with $50 \%$ methanol in $0.1 \%$ formic acid or $0.1 \%$ formic acid and $3 \% \mathrm{ACN}$, respectively, according to protocols indicated in Table ${ }^{\circ}$.Samples ${ }^{\circ}$ were ${ }^{\circ}$ ipTipC $_{18}$ cleaned as required (Table ${ }^{\circ}$ ).

As a control, empty gel digests were prepared, using a standard protein-free empty resolving gel; 1D SDS-PAGE was not performed for these control samples. Empty gel pieces were cut into small pieces of equal size $(3 \mathrm{~mm}$ diameter). Gel digests were obtained after performing the protocol detailed above. Dry digests were stored at $-20^{\circ} \mathrm{C}$. The tryptically digested samples $(10 \mu \mathrm{L}$ of each sample) were spiked into each empty gel digest residues, and the mixture was stored, according to Protocols ${ }^{\circ} \mathrm{C} 1,{ }^{\circ} \mathrm{C} 2{ }^{\circ}$ and ${ }^{\circ} \mathrm{D}^{\circ}$ indicated ${ }^{\circ}$ in ${ }^{\circ} \mathrm{Table}^{\circ} 1$.

\section{ZipTip Sample Cleanup}

The samples were prepared for MS analysis with ZipTipC $_{18^{\circ}}$ 'leanup ${ }^{\circ}$ according ${ }^{\circ}$ to ${ }^{\circ}$ Table $^{\circ} 1$, and ${ }^{\circ}$ following the manufacturer's protocol (User Guide for ReversedPhase ZipTip, Millipore Corporation). After the peptides were eluted using $20 \mu \mathrm{L}$ of methanol with $0.1 \%$ formic acid, the samples were completely dried in a vacuum concentrator and stored at $-20{ }^{\circ} \mathrm{C}$ until required. Before use, the samples were diluted with $50 \%$ methanol in $0.1 \%$ formic acid for the CB-ESI or $0.1 \%$ formic acid and 3\% ACN for the HPLC-ESI, assuming a $100 \%$ recovery yield in the ZipTip cleanup step.

\section{Sample Analysis by Automated CB-ESI-MS/MS}

All analyses were performed with a QStar XL Hybrid ESI Quadrupole TOF tandem mass spectrometer, ESI QqTOF-MS/MS (Applied Biosystems, Framingham, MA; MDS-SCIEX, Concord, Ontario, Canada). The automated CB-ESI system used was the NanoMate HD (Advion BioSciences, Ithaca, NY), which infuses the sample through the ESI Chip HD. The ESI Chip HD consists of a $20 \times 20$ array of nozzles, with the capabil-

Table 1. Summary of compared sample preparation protocols (all followed by on-line QStarXL hybrid ESI quadrupole TOF tandem mass spectrometry)

\begin{tabular}{|c|c|c|c|c|c|c|c|}
\hline Protocol & $\begin{array}{l}\text { Cytochrome } c \\
\text { standard } \\
\text { digest }\end{array}$ & $\begin{array}{l}\text { Six-protein } \\
\text { mixture } \\
\text { standard } \\
\text { digest }\end{array}$ & $\begin{array}{c}\text { Cytochrome c } \\
\text { using 1D SDS } \\
\text { PAGE and } \\
\text { in-gel tryptic } \\
\text { digestion }\end{array}$ & $\begin{array}{l}\text { Empty gel } \\
\text { tryptic } \\
\text { digests }\end{array}$ & $\begin{array}{l}\text { ZipTip }_{18} \\
\text { cleanup }\end{array}$ & $\begin{array}{c}\text { Concentration } \\
\text { (each protein; } \\
\text { fmol } / \mu \mathrm{L} \text { ) }\end{array}$ & Source type ${ }^{a}$ \\
\hline A1 & $\checkmark$ & $\checkmark$ & & & & $\begin{array}{r}500 \\
50\end{array}$ & CB-ESI \\
\hline A2 & $\checkmark$ & $\checkmark$ & & & & $\begin{array}{r}500 \\
50\end{array}$ & $\begin{array}{l}\text { HPLC-ESI } \\
\text { (12-min, isocratic) }\end{array}$ \\
\hline B1 & $\checkmark$ & $\checkmark$ & & & $\checkmark$ & $\begin{array}{r}500 \\
50\end{array}$ & CB-ESI \\
\hline B2 & $\checkmark$ & $\checkmark$ & & & $\checkmark$ & $\begin{array}{r}500 \\
50\end{array}$ & $\begin{array}{l}\text { HPLC-ESI } \\
\text { (12-min, isocratic) }\end{array}$ \\
\hline $\mathrm{C} 1$ & $\checkmark$ & $\checkmark$ & & $\checkmark$ & & $\begin{array}{r}500 \\
50\end{array}$ & CB-ESI \\
\hline $\mathrm{C} 2$ & $\checkmark$ & $\checkmark$ & & $\checkmark$ & & $\begin{array}{r}500 \\
50\end{array}$ & $\begin{array}{l}\text { HPLC-ESI } \\
\text { (12-min, isocratic) }\end{array}$ \\
\hline D & $\checkmark$ & $\checkmark$ & & $\checkmark$ & $\checkmark$ & $\begin{array}{r}500 \\
50\end{array}$ & CB-ESI \\
\hline E1 & & & $\checkmark$ & & & 500 & $\begin{array}{l}\text { HPLC-ESI } \\
\text { (12-min, isocratic) }\end{array}$ \\
\hline E2 & & & $\checkmark$ & & & 500 & CB-ESI \\
\hline$F$ & & & $\checkmark$ & & $\checkmark$ & 500 & CB-ESI \\
\hline
\end{tabular}

aDifferent sources indicate different workflows: (1) CB-ESI; (2) HPLC-ESI 12 min (i.e., LC-12); and (3) HPLC-ESI isocratic (i.e., LC-isocratic). 
ity to sequentially analyze up to 400 samples. The NanoMate employs a 384-well plate, a rack of 96 disposable, conductive pipette tips, and the chip, which was positioned $\sim 5 \mathrm{~mm}$ from the orifice of the QStar. The system, controlled by ChipSoft software (Version 6.4.2, Advion BioSciences), sequentially picks up a new pipette tip and aspirates $5 \mu \mathrm{L}$ of sample from the 384-well plate, which contains $5 \mu \mathrm{L}$ of sample per well. The plates were sealed with an adhesive aluminium-foil film (Corning BV, Schiphol-Rijk, The Netherlands). The sample was delivered to the inlet side of the 400 nozzle ESI chip. Nanoelectrospray was carried out by applying a $1.65 \mathrm{kV}$ spray voltage and a $0.3 \mathrm{psi}(2.07 \mathrm{kPa})$ nitrogen head pressure to the sample in the pipette tip. Typical infusion flow rates were $200 \mathrm{~nL} / \mathrm{min}$. Following sample infusion and MS analysis, the pipette tip was ejected. Since a dedicated pipette tip and nozzle were used for each sample, there was no sample carryover. The mass spectrometer was operated using an IDA setup. Each experiment consisted of 22 cycles, each cycle consisting of one TOF-MS survey scan (1, 3, 5, and $10 \mathrm{~s})$ and eight subsequent MS/MS scans (1, 3, and $10 \mathrm{~s}$ each). Triplicate experiments were conducted. Doubly and triply charged ions were selected for MS/MS. Several combinations of survey scan and MS/MS acquisition times were evaluated to determine an optimal IDA protocol (Table $\left.{ }^{\circ} 2\right){ }^{\circ}{ }^{\circ}$ The $^{\circ}$ ion $^{\circ}$ source $^{\circ}$ gas $^{\circ}$ was $^{\circ}$ set $^{\circ}$ to $^{\circ} 50^{\circ}$ psi, $^{\circ}$ survey scans were acquired from 350 to $1800 \mathrm{~m} / \mathrm{z}$, MS/MS scans from 65 to $1800 \mathrm{~m} / z$, and the collision energy and collision gas were set to $0 \mathrm{~V}$ and 4.0 psi, respectively. Replicate $^{\circ}$ samples $^{\circ}$ were $^{\circ}$ analyzed $^{\circ}\left(\right.$ Table $\left.^{\circ} 1\right)$.

MS/MS data were analyzed using Mascot (Matrix Science Inc., London, UK) software for protein identification, giving the peptide coverage percentage and a $\mathrm{MOWSE}^{\circ}$ score $^{\circ}[43] .^{\circ}{ }^{\circ} \mathrm{The}^{\circ} \mathrm{MS} / \mathrm{MS}^{\circ}{ }^{\text {spectral }}{ }^{\circ}$ values ${ }^{\circ}$ were compared with fragment ion mass values to identify proteins from primary sequence databases. Results of two different primary sequence general databases were compared throughout the study. These were the entire MSDB database (September 2005) and NCBI nonredundant (NR) database (March 2004). In the case of alcohol dehydrogenase and $\beta$-galactosidase, the specific Saccharomyces cerevisiae and Escherichia coli MSDB databases, respectively, were searched to compare results. The peptide tolerance was set to $1.2 \mathrm{Da}$, the MS/MS toler-

Table 2. Experimental set-up on a QStarXL system for CB-ESI evaluation

\begin{tabular}{|c|c|c|c|}
\hline \multirow[b]{2}{*}{ Survey scan times (s) } & \multicolumn{3}{|c|}{$\begin{array}{l}\text { Experiment duration (min) for } \\
\text { each combination of survey } \\
\text { scan time and MS/MS scan } \\
\text { time }\end{array}$} \\
\hline & $1 \mathrm{~s}$ & $3 s$ & $10 \mathrm{~s}$ \\
\hline 1 & 3.3 & 9.2 & 9.7 \\
\hline 3 & 4.0 & 9.9 & 30.4 \\
\hline 5 & 4.8 & 10.6 & 31.2 \\
\hline 10 & 6.6 & 12.5 & 33.0 \\
\hline
\end{tabular}

ance was set to $0.6 \mathrm{Da}$, up to one missed cleavage was allowed, +2 and +3 charged ions were considered, and carboxymethyl (C) and oxidation (M) were also set as fixed and variable modifications, respectively. ESIQUAD-TOF was the set instrument. Furthermore, a comparison of the Mascot results after 11 and 22 cycles (half and whole spectra) was carried out.

\section{Sample Analysis by HPLC-ESI-MS/MS}

Protein identification using HPLC-ESI-MS/MS was performed under the same experimental conditions to directly compare the results obtained by CB-ESI-MS / MS. Peptide mixtures were separated using a LC Packings Ultimate system (Amsterdam, The Netherlands); 5 $\mu \mathrm{L}$ of extracted peptide solution was injected by the Famos autosampler onto a $0.3 \mathrm{~mm}$ i.d. $\times 5 \mathrm{~mm}$ o.d. trap column (m-Precolumn Cartridge; PepMap C18, $5 \mu \mathrm{m}$, $100 \AA$ ) at a flow rate of $300 \mathrm{~nL} / \mathrm{min}$. Separation was performed using a $0.075 \times 150 \mathrm{~mm}$ reverse-phase capillary column (C18 PepMap100, $3 \mu \mathrm{m}, 100 \AA$, $75 \mu \mathrm{m}$ i.d. $\times 15 \mathrm{~cm}$ ) and a flow rate of $300 \mathrm{~nL} / \mathrm{min}$. HPLC-ESI solvents contained $0.1 \%$ formic acid and either $3 \% \mathrm{ACN}$ (Solvent A) or $97 \%$ ACN (Solvent B). The column was pre-equilibrated with Solvent A. Separation of the peptides was performed by two protocols: (1) isocratic elution (LC-isocratic), of 55\% solvent B for $12.5 \mathrm{~min}$; and (2) a linear gradient from 5 to $55 \%$ Solvent B, in 12.5 min (LC-12). The duration of the sample delivery was set according to the length of the optimal CB-ESI experiment determined, for comparison reasons. For both protocols, each experiment was performed in $25 \mathrm{~min}$. Triplicate experiments were conducted. The electrospray fused silica PicoTip needle (New Objective, Inc., Woburn, MA) was operated with a voltage differential of $5.5 \mathrm{kV}$. Survey scans were acquired from 350 to 1800 $m / z$, and MS/MS scans from 65 to $1800 \mathrm{~m} / z$. The spectrometer sequentially conducted MS/MS on the precursor ions ( +2 and +3 charge state) detected in the full scan. Protein identification was carried out with Mascot, as described above.

\section{Results and Discussion}

\section{Sample Preparation Effects}

To determine the effect of sample concentration, $5 \mu \mathrm{L}$ of 500 and $50 \mathrm{fmol} / \mu \mathrm{L}$ aliquots (2500 and $250 \mathrm{fmol}$ of each protein, respectively) of both the individual cytochrome $c$ and the six-protein mixture digests were analyzed using both CB-ESI (Protocol A1) and HPLC-ESI (Protocol A2) sources. The duration of the experiment using CB-ESI was $30.4 \mathrm{~min}$ (with $3 \mathrm{~s}$ MS and $10 \mathrm{~s}$ MS/MS scans). To evaluate the effect of $Z_{i p T i p C}$ cleanup (Protocols B1 and B2) and in-gel digestion, residues of empty gel tryptic digestion were added to the aliquots (Protocols C1 and C2) and ZipTip cleanup was performed (Protocol D). The ZipTip sample cleanup before HPLC-ESI sample introduction (Protocol B2) was per- 
formed to study its effect, even though it is not required for this work flow. To confirm the in-gel digestion effect on the subsequent MS analysis using the CB-ESI sample introduction work flow, $7 \mu \mathrm{g}$ of cytochrome $c$ were digested in-gel after 1-D SDS-PAGE (Protocols E1, E2 and F). As Mascot calculates the MOWSE score (probability of an identical match to each peptide from the MS/MS) based on the fragment ion series found and the ${ }^{\circ}$ mass $^{\circ}$ accuracy $^{\circ}$ of ${ }^{\circ}$ the ${ }^{\circ}$ spectra $^{\circ}[44],{ }^{\circ}$ the ${ }^{\circ}$ following analysis considers that a low MOWSE score indicates either low peptide ion relative intensities or an incomplete fragment ion series, both depending on the capability of the MS to detect the peptides.

Single protein study. Cytochrome $c$ was used to study the effects of sample preparation on the identification of a single protein. The MOWSE score and peptide coverage obtained via the LC-isocratic work flow were generally the highest, followed by the LC-12 and CB-ESI sample introduction work flows (compare infusion type results within the groups of datasets A-C, D-F, G-I, J-L, and ${ }^{\circ} \mathrm{M}-\mathrm{O}^{\circ}$ in $^{\circ}$ Figure $\left.^{\circ} 1\right) .{ }^{\circ}$ One ${ }^{\circ}$ exception ${ }^{\circ}$ to $^{\circ}$ this ${ }^{\circ}$ trend ${ }^{\circ}$ was a higher peptide coverage resulting from the CB-ESI work flow than those obtained from LC-12 infusion method when no sample cleanup was performed after in-solution digestion (compare infusion type peptide coverage results in datasets $A$ versus $C$ and $D$ versus $F$ in $^{\circ}$ Figure $\left.^{\circ} 1\right),{ }^{\circ}$ and $^{\circ}$ sample $^{\circ}$ Cleanup $^{\circ}$ after $^{\circ}$ in-gel ${ }^{\circ}$ digestion (compare infusion type peptide coverage results in datasets $^{\circ} \mathrm{M}^{\circ}$ versus $^{\circ} \mathrm{O}^{\circ}$ in $^{\circ}$ Figure $\left.^{\circ} 1\right) .^{\circ} \mathrm{As}^{\circ}$ expected, ${ }^{\circ}$ the results indicate a detrimental effect after ZipTip sample cleanup regardless of the source type (Protocols B1 and B2 in Table 1): ${ }^{\circ}{ }^{\circ}$ decrease in both the MOWSE ${ }^{\circ}$ score ${ }^{\circ}$ and protein coverage occurred for tryptically digested samples $^{\circ}$ without ${ }^{\circ}$ previous $^{\circ}$ spiked-in blank $^{\circ}$ gel $^{\circ}$ digests $^{\circ}(\mathrm{com}-$ pareinfusion type results within ${ }^{\circ}$ atasets ${ }^{\circ} \mathrm{A}-\mathrm{F}^{9}$ in Figure 1 ). Meanwhile, for those samples with added in-gel digested $^{\circ}$ residues $^{\circ}\left(\right.$ Protocols $^{\circ} \mathrm{C}^{\circ}$ and $^{\circ} \mathrm{D}^{\circ}$ in $^{\circ} \mathrm{Table}^{\circ} 1$ ), ${ }^{\circ}$ an improvement in both score and coverage was achieved (compare results under CB-ESI infusion type, datasets I and ${ }^{\circ} \mathrm{L}^{\circ}$ in ${ }^{\circ}$ Figure $\left.^{\circ} 1\right)^{\circ}$ when ${ }^{\circ}$ using ${ }^{\circ}$ the ${ }^{\circ} \mathrm{CB}-\mathrm{ESI}^{\circ}$ work ${ }^{\circ}$ flow . This effect is probably due to the residues of in-gel digestion, which can create a considerable amount of background noise, or can interfere with ionization efficiency. This was particularly important for the low concentration $^{\circ}\left(50^{\circ} \mathrm{fmol} / \mu \mathrm{L},{ }^{\circ}\right.$ dataset $^{\circ} \mathrm{L}^{\circ}$ in $^{\circ}$ Figure $\left.^{\circ} 1\right)$, where non-cleaned samples resulted in no peptide detection. The closest LC-12 agreement to the scores obtained using the CB-ESI introduction work flow scores and coverage was for the $500 \mathrm{fmol} / \mu \mathrm{L}$ without prior sample cleanup for both in-solution and in-gel digestion (compare datasets $\mathrm{A}$ and $\mathrm{C}, \mathrm{M}$ and $\mathrm{O}$ in Figure $\left.{ }^{\circ} 1\right) .{ }^{\circ}$ These $^{\circ}$ results $^{\circ}$ show $^{\circ}$ that $^{\circ}$ with $^{\circ}$ higher $^{\circ}$ sample concentration (in the range tested here), protein identifications with higher confidence (MOWSE score) and higher sequence coverage are possible. This trend can be attributed to an increased ion count and detection of low-abundance peptides. The detection limit was 50 $\mathrm{fmol} / \mu \mathrm{L}$ (45 and 10 overall standard deviation for MOWSE score and peptide coverage, respectively).

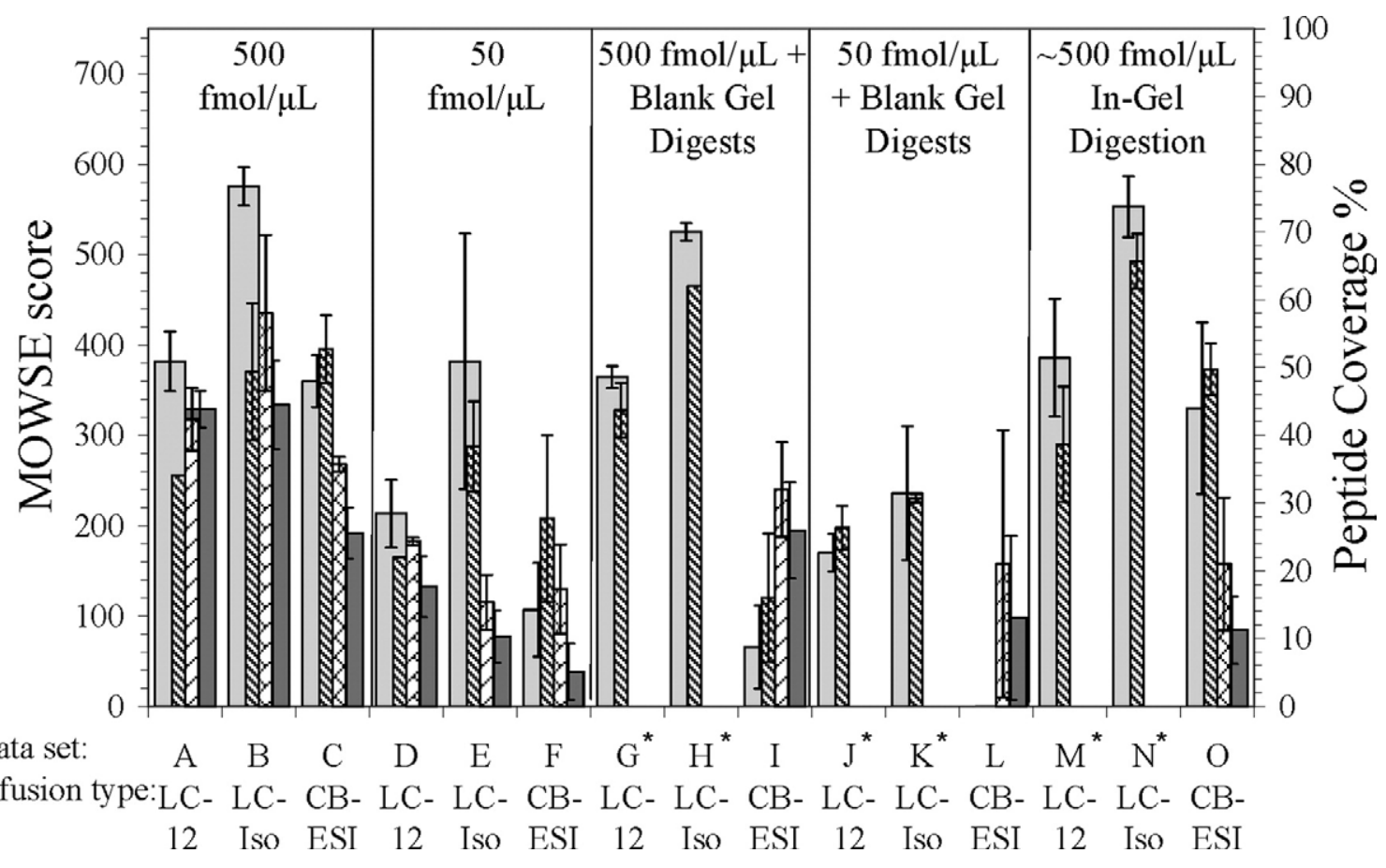

Figure 1. Variation of MOWSE score and peptide coverage of cytochrome $c$ comparing ZipTip cleanup and sample concentration, for different work flows. Score without ZipTip ( $\square$ ); score with

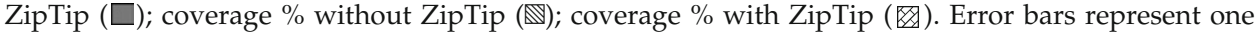
standard deviation of three replicate analyses. Datasets marked with an asterisk indicate cases in which no sample cleanup was outperformed (not necessary prior HPLC-ESI). 
Table 3. Cytochrome $c$ and $\beta$-galactosidase peptides detected with tandem MS, without and with ZipTip sample cleanup

\begin{tabular}{|c|c|c|}
\hline Protein & Detected peptides without sample cleanup & Detected peptides with sample cleanup \\
\hline Cytochrome $c$ & KTGQAPGFSYTDANK & MIFAGIK \\
\hline \multirow[t]{3}{*}{ LC-isocratic workflow } & & TGPNLHGLFGR \\
\hline & & TGQAPGFSYTDANK \\
\hline & & KTGQAPGFSYTDANK \\
\hline Cytochrome $c$ & TGPNLHGLFGR & EDLIAYLK \\
\hline \multirow[t]{2}{*}{ CB-ESI workflow } & TGQAPGFSYTDANK & TGQAPGFSYTDANK \\
\hline & & KTGQAPGFSYTDANK \\
\hline$\beta$-galactosidase & GDFQFNISR & GDFQFNISR \\
\hline \multirow[t]{7}{*}{ CB-ESI workflow } & DWENPGVTQLNR & HQQQFFQFR \\
\hline & APLDNDIGVSEATR & ELNYGPHOWR \\
\hline & IGLNCQLAQVAER & DWENPGVTQLNR \\
\hline & VNWLGLGPQENYPDR & APLDNDIGVSEATR \\
\hline & IENGLLLLNGKPLLIR & IGLNCQLAQVAER \\
\hline & & YSQQQLMETSHR \\
\hline & & VNWLGLGPQENYPDR \\
\hline
\end{tabular}

Although in the past we have detected $25 \mathrm{fmol}(5 \mu \mathrm{L}$ of $5 \mathrm{fmol} / \mu \mathrm{L}$ sample) (data not shown), we found this to be not reproducible. The actual detection limit thus appears to lie between 25 and $250 \mathrm{fmol}$. The effect of different sample preparations on the analysis of this small protein (resulting in only six amenable tryptic peptides) is highly noticeable since the detection of an additional peptide considerably increases the peptide coverage and score.
Six-protein mixture study. Since CB-ESI can also be used for complex peptide samples, the effects of sample preparation were evaluated for the six-protein mixture. The effects of sample concentration were similar to those found in the single protein study. As with the results obtained for cytochrome $c$ alone, ZipTip cleanup was found to have an important effect on the protein score and coverage for both HPLC-ESI and CB-ESI work flows, generally resulting in decreased score and

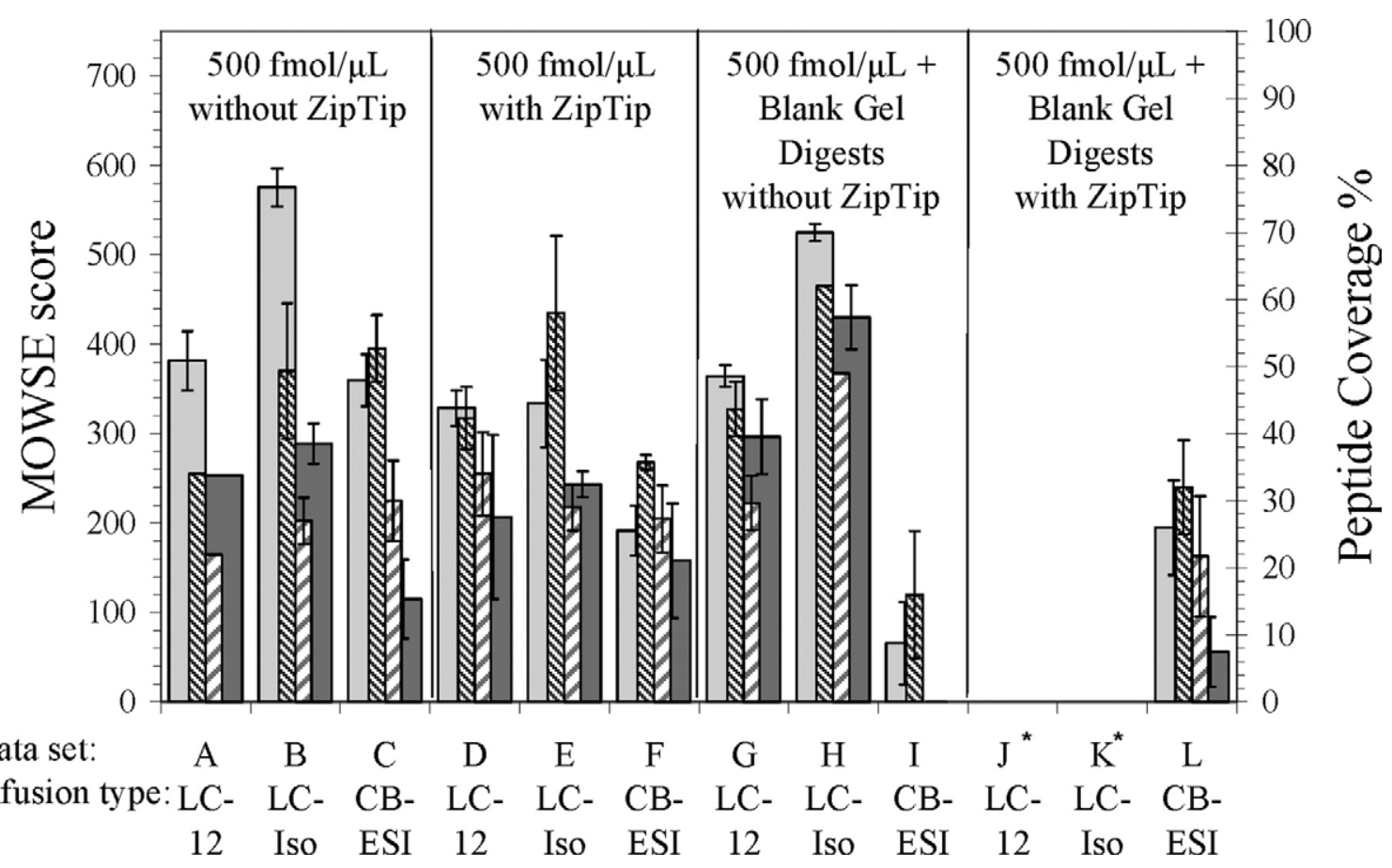

Figure 2. Variation of MOWSE score and peptide coverage of cytochrome $c$ analyzed as a single protein and in a protein mixture, with and without ZipTip cleanup, for different sources. Score single protein $(\square)$; score protein in mix $(\square)$; peptide coverage $\%$ single protein $(\mathbb{\mathbb { V }})$; peptide coverage $\%$ protein in mix (图). Scores correspond to MOWSE score axis and cross-hatched columns refer to peptide coverage axis. Error bars represent one standard deviation of three replicate analyses. Datasets marked with an asterisk indicate cases in which no sample cleanup was outperformed (not necessary prior HPLC-ESI). 


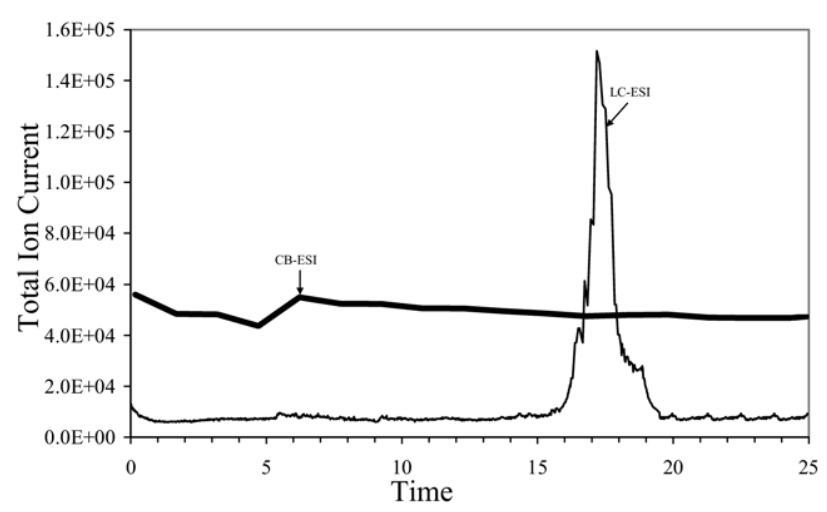

Figure 3. Comparison of total ion current for HPLC-ESI (LC-12) (-) versus CB-ESI (10 s survey scans and $1 \mathrm{~s}$ MS/MS scans) (-) of cytochrome $c$ at $500 \mathrm{fmol} / \mu \mathrm{L}$. Using HPLC-ESI, each of the concentrated peptide fractions $(2.5 \mathrm{pmol})$ elute in a short time window (all within the observed peak), while with CB-ESI the sample eluted constantly throughout the analysis at a lower but prolonged protein infusion rate $(100 \mathrm{fmol} / \mathrm{min})$.

coverage for each protein in samples without in-gel digestion and increased score and coverage in samples with in-gel digestion (data not shown). However, there were two exceptions to this trend: cytochrome $c$ (LCisocratic and CB-ESI work flow) and $\beta$-galactosidase (CB-ESI work flow) MOWSE scores (increased up to $\sim 35 \%$ and $\sim 20 \%$, respectively) and protein coverage (increased up to $\sim 110 \%$ and $\sim 15 \%$, respectively) were higher after ZipTip cleanup of samples without in-gel digestion (data not shown). This could have been caused by the mass spectrometer being able to detect peptides that were previously suppressed by high abundance peptides, after the latter were lost due to the ZipTip $\mathrm{C}_{18^{\circ}}$ cleanup $^{\circ}$ (see ${ }^{\circ}$ Table 3 ). In ${ }^{\circ}$ particular, ${ }^{\circ}$ the 9 high increment in protein coverage of cytochrome $c$ is due to its small size, where one more detected peptide notably improves its coverage. The suppression of small peptide Ions, previously ${ }^{\circ}$ observed by ${ }^{\circ}$ Sterner ${ }^{\circ} t^{\circ}$ al. [45], who determined the suppression of the signal of smaller molecules by the presence of large molecules when analyzed from an ESI source, was also clear when the score and coverage of cytochrome $c$ in the mixture were considerably lower than comparable results from the single protein analyses, for both CB-ESI and HPLC-ESI work ${ }^{\circ}$ flows $^{\circ}$ (all ${ }^{\circ}$ columns $^{\circ}$ in ${ }^{\circ}$ Figure 2 ). In ${ }^{\circ}$ all ${ }^{\circ}$ cases, ${ }^{\circ}$ except after in-gel digestion without ZipTip cleanup, CB-ESI

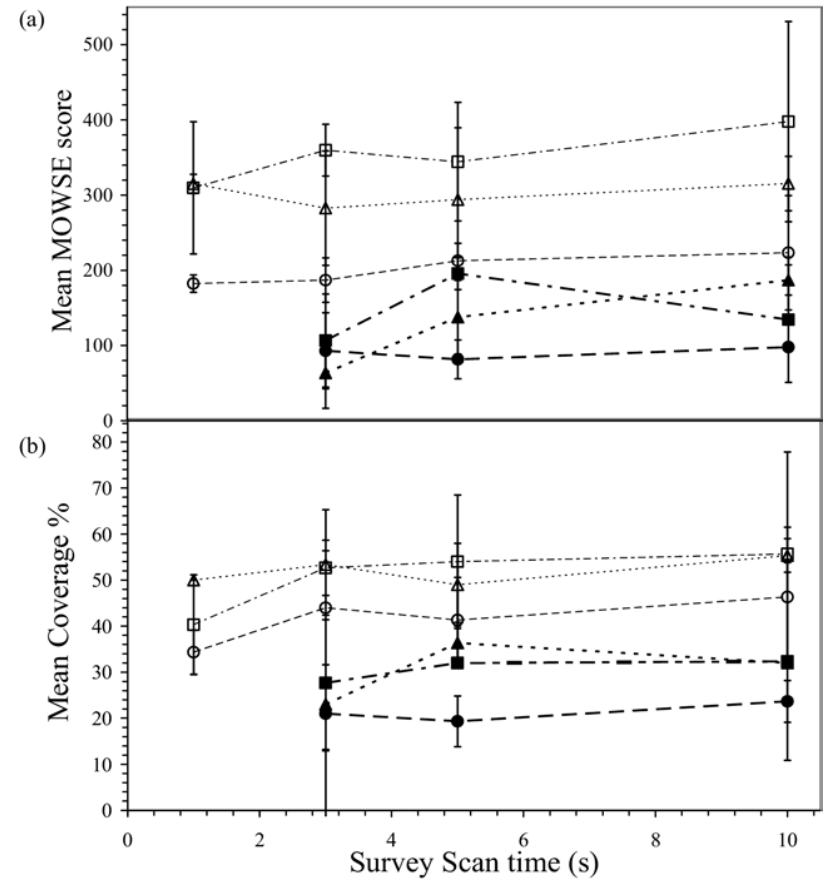

Figure 4. Evaluation of CB-ESI scan times: the effects of survey scan time, MS/MS scan time, and concentration for cytochrome $c$. (a) MOWSE score and (b) peptide coverage. No positive ID was obtained for $5 \mathrm{fmol} / \mu \mathrm{L} ; 1 \mathrm{~s}$ MS/MS $500 \mathrm{fmol} / \mu \mathrm{L}(\bigcirc)$; $3 \mathrm{~s}$ MS /MS $500 \mathrm{fmol} / \mu \mathrm{L}(\Delta) ; 10 \mathrm{~s}$ MS $/ \mathrm{MS} 500 \mathrm{fmol} / \mu \mathrm{L}(\square) ; 1 \mathrm{~s}$ MS/MS 50 $\mathrm{fmol} / \mu \mathrm{L}(\bullet) ; 3 \mathrm{~s}$ MS $/ \mathrm{MS} 50 \mathrm{fmol} / \mu \mathrm{L}(\mathbf{\Delta}) ; 10 \mathrm{~s}$ MS/MS 50 $\mathrm{fmol} / \mu \mathrm{L}(\boldsymbol{\square})$. Error bars represent one standard deviation of three replicate analyses.

sample introduction enabled the identification of all of the proteins in the mixture with improved scores and peptide coverage compared with the LC-isocratic work flow.

\section{Optimal CB-ESI IDA Protocol: Effect of Survey and MS/MS Scan Times}

In contrast to the traditional HPLC-ESI work flow, samples are constantly infused via CB-ESI, allowing for longer MS analyses if needed. The rate of sample infusion from the CB-ESI device $(100 \mathrm{fmol} / \mathrm{min}$ of whole peptide mixture based on 2.5 pmol total cytochrome $c$ infused) was constant throughout the analysis, while the rate of sample infusion $(2.5 \mathrm{pmol}$ of total

Figure 5. (a) Effect of CB-ESI analysis parameters on individual cytochrome $c$ peptide MOWSE scores as a function of MS/MS scan time at a fixed $10 \mathrm{~s}$ survey scan time, for 500 and $50 \mathrm{fmol} / \mu \mathrm{L}$ protein concentration. R.KTGQAPGFSYTDANK.N $500 \mathrm{fmol} / \mu \mathrm{L}, \mathrm{MH}_{3}^{3+}(\diamond) ; \mathrm{K}$.TGPNLHGLFGR.K 500 $\mathrm{fmol} / \mu \mathrm{L}(\square)$; K.TGQAPGFSYTDANK.N $500 \mathrm{fmol} / \mu \mathrm{L}(\bigcirc)$; R.KTGQAPGFSYTDANK.N $500 \mathrm{fmol} / \mu \mathrm{L}$, $\mathrm{MH}_{2}^{2+}(\triangle)$; R.KTGQAPGFSYTDANK.N $50 \mathrm{fmol} / \mu \mathrm{L}, \mathrm{MH}_{3}^{3+}(\diamond)$; K.TGPNLHGLFGR.K $50 \mathrm{fmol} / \mu \mathrm{L}$ (ם); K.TGQAPGFSYTDANK.N $50 \mathrm{fmol} / \mu \mathrm{L}(\bullet)$; R.KTGQAPGFSYTDANK.N $50 \mathrm{fmol} / \mu \mathrm{L}, \mathrm{MH}_{2}^{2+}(\mathbf{\Delta})$. (b) MS/MS spectra for doubly charged peptide KTGQAPGFSYTDANK indicating b and y ions. Increased MS/MS scan time resulted in some larger peptide fractions ( $\geq 700 \mathrm{Da})[\mathrm{b}(10), \mathrm{y}(9)$, and y (13)] being undetected, whilst some new smaller peptides (<700 Da) $\left[\mathrm{b}^{0}(2), \mathrm{b}^{*++}(3), \mathrm{b}^{*}(4), \mathrm{b}^{0++}(13)\right]$ were detected. This peptide degradation phenomena may be responsible for the unusual decrease in MOWSE score after an increase in MS/MS scan time on this doubly charged peptide. 
(a)

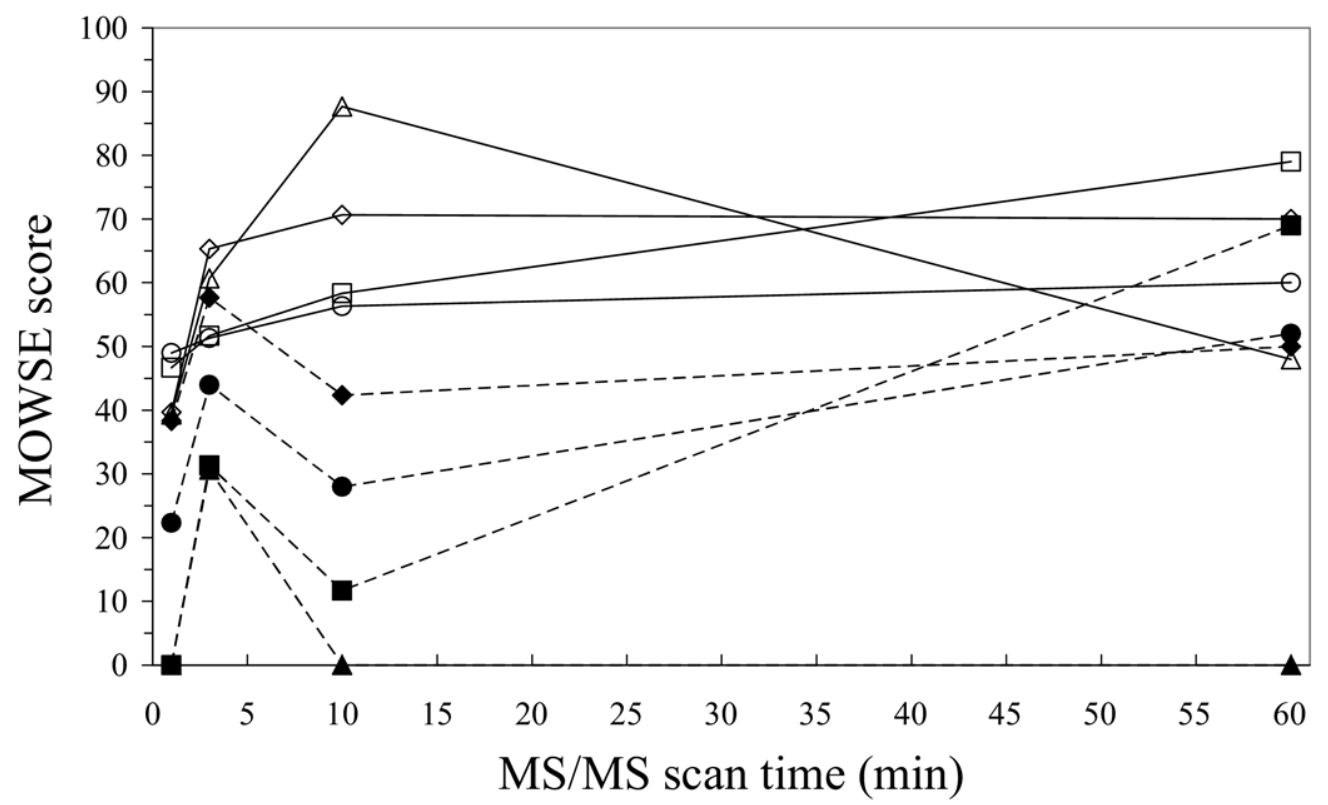

(b)

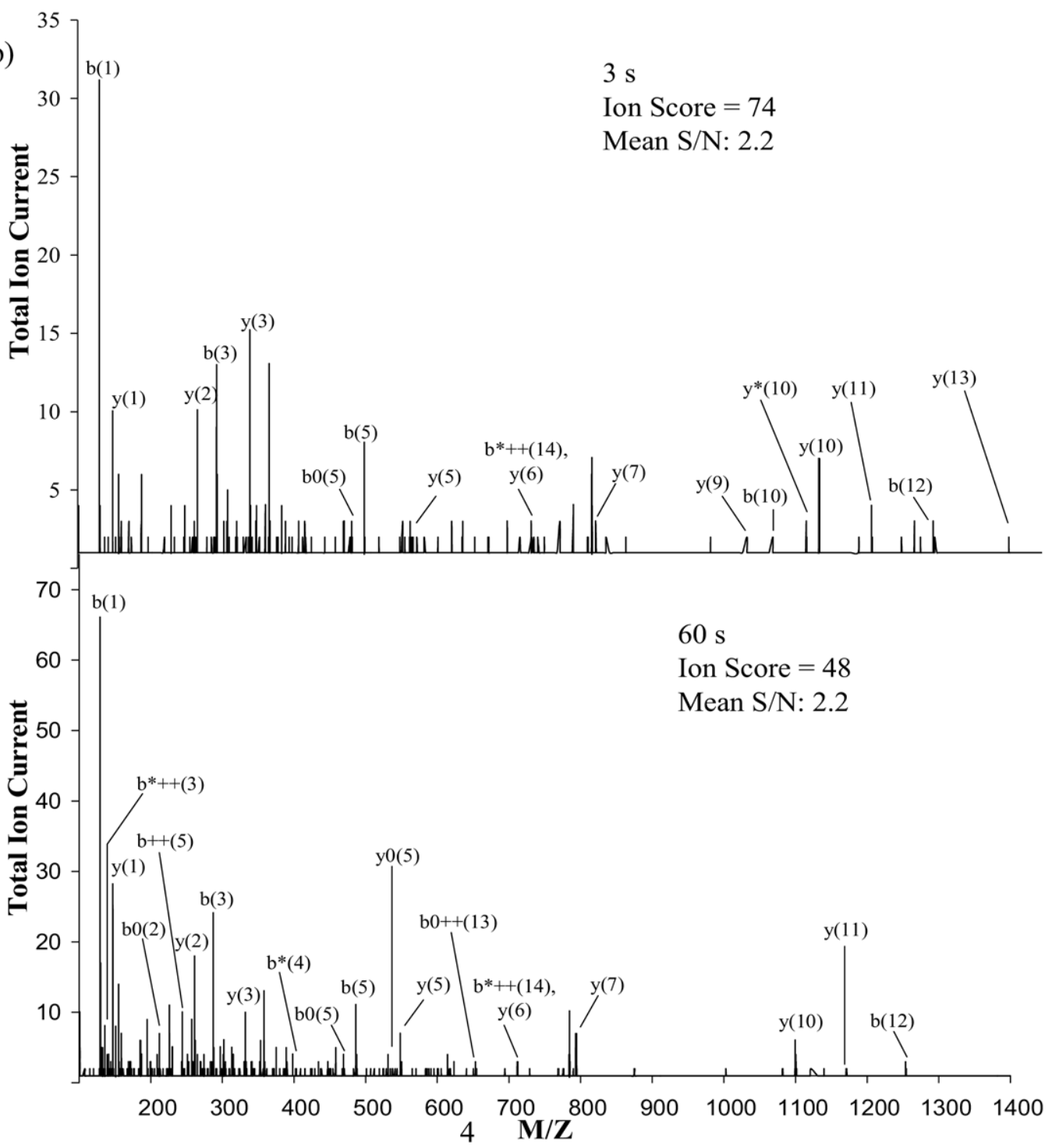


cytochrome $c$ infused) from the HPLC-ESI device varied throughout the infusion, as each peptide was initially separated and concentrated in the column, eluting within a shorter period of time ( $2.5 \mathrm{pmol}$ of each tryptic peptide in each period). For example, a single peptide, 1169.64 Da, was eluted at the highest peak of the spectrum $^{\circ}\left(\text { Figure }^{\circ} 3\right)^{\circ}$ all $^{\circ}$ within $^{\circ} \sim 66^{\circ} \mathrm{s}^{\circ}\left(\right.$ data $^{\circ}$ not $^{\circ}$ shown . The CB-ESI device allows for an extended time of infused sample to acquire more scans in both MS and MS/MS modes if needed. This approach is expected to provide sufficient acquisition time for selecting lowabundance ions for MS/MS in IDA experiments, which compensates for the absence of LC-based concentration effects, and may improve detection sensitivity and protein $^{\circ}$ sequence $^{\circ}$ coverage $^{\circ}[9]$.

To determine the sample concentration detection limit of the CB-ESI device, in-solution digested proteins at 500 and $50 \mathrm{fmol} / \mu \mathrm{L}$ were analyzed (Protocols A1 and A2, ${ }^{\circ}$ Table $\left.^{\circ} 1\right) .^{\circ}$ Various $^{\circ}$ IDA $^{\circ}$ protocols $^{\circ}$ with $^{\circ}$ different survey $(1,3,5$, and $10 \mathrm{~s})$ and MS/MS (1, 3, 10, and $60 \mathrm{~s})$ scan times were evaluated for both protein concentrations $^{\circ}\left(\right.$ Table $\left.^{\circ} 2\right) .^{\circ}$ An $^{\circ}$ analysis $^{\circ}$ of $^{\circ}$ the $^{\circ}$ effects $^{\circ}$ of the $^{\circ}$ major IDA parameters was carried out by considering positive protein identification, degree of agreement with HPLCESI results, reproducibility of the results, and length of the experiment. An optimal IDA protocol for the protein mixture was determined.

Single protein study. As before, higher protein concentrations resulted in improved MOWSE scores and protein coverage, and the lower limit for protein identification employing CB-ESI was a concentration of 50 $\mathrm{fmol} / \mu \mathrm{L}^{\circ}$ of $^{\circ}$ each $^{\circ} \operatorname{protein}^{\circ}\left(\right.$ Figure $\left.^{\circ} 4\right){ }^{\circ} \mathrm{We}^{\circ}$ also $^{\circ}$ tested $^{\circ} 5$ $\mathrm{fmol} / \mu \mathrm{L}$ concentration ( $1 \mathrm{fmol} / \mathrm{min}$ sample infusion) for each condition, and did not obtain reproducible or useable data (data not shown). MOWSE scores and protein coverage increased with increasing MS/MS scan time (1 to $10 \mathrm{~s} / \mathrm{scan}$ ) for the 500 and $50 \mathrm{fmol} / \mu \mathrm{L}$ mixtures. Generally, no major improvement in score and coverage with increasing survey scan times beyond $3^{\circ} \mathrm{s}^{\circ}$ was $^{\circ}$ observed $^{\circ}\left(\right.$ Figure $^{\circ} 4 \mathrm{a}^{\circ}$ and $\left.{ }^{\circ} \mathrm{b}\right) .^{\circ}$ The $^{\circ}$ more $^{\circ}$ variable results $^{\circ}$ observed $^{\circ}$ in $^{\circ}$ Figure $^{\circ} 4^{\circ}$ for ${ }^{\circ}$ low $^{\circ}$ concentration proteins may be due to the stochastic nature of the mass spectrometer for low abundance peptide detection. In the case of cytochrome $c$, the detection (or lack thereof) of a single peptide will greatly affect the score and coverage since it is a small protein. The MOWSE score of the overall protein is the sum of the MOWSE scores of each of the individual constituent peptides. Hence, the effect of increasing MS/MS time (from 1 to $60 \mathrm{~s} / \mathrm{cycle}$ ) on specific peptides identified from cytochrome $c$ was evaluated, ${ }^{\circ}$ with $^{\circ}$ results $^{\circ}$ depicted $^{\circ}$ in $^{\circ}$ Figure $^{\circ} 5 a .^{\circ}$ Again, MOWSE scores generally did not improve for MS/MS scan times greater than $3 \mathrm{~s}$, and a lower protein concentration resulted in more variable results. Only two peptide scores were higher when scan times were longer than 3 s: (1) TGPNLHGLFGR (44\% increment), for which the longer MS/MS time may have improved the accurate detection of this small peptide; and (2) doubly charged KTGQAPGFSYTDANK (55\% increment), for which peptide degradation may be responsible for the unusual decrease, after an increase of score, with $^{\circ}$ increased $^{\circ} \operatorname{scan}^{\circ}$ time $^{\circ}\left(>10^{\circ} \mathrm{s}^{\circ}\left(\right.\right.$ Figure $\left.^{\circ} 5 \mathrm{~b}\right) .^{\circ}$ The shortest experiment time that allowed identification of $500 \mathrm{fmol} / \mu \mathrm{L}$ cytochrome $c$ was $3.3 \mathrm{~min}$ (1 s survey and $1 \mathrm{~s}$ MS/MS scan times) with a MOWSE score of 182 and $34 \%$ protein coverage, while a $4 \mathrm{~min}$ ( 3 s survey and $1 \mathrm{~s}$ MS/MS scan times) experiment could identify 50 $\mathrm{fmol} / \mu \mathrm{L}$ with a score of 93 and $21 \%$ protein coverage (Figure $\left.{ }^{\circ} 4\right) .{ }^{\circ}$ The $^{\circ} \mathrm{MOWSE}^{\circ}$ Scores $^{\circ}$ and $^{\circ}$ coverage $^{\circ}$ are ${ }^{\circ}$ lower than the ones obtained with the LC-12 $(44 \%-48 \%$ of scores and 95\%-101\% coverage) and LC-isocratic (24\%$32 \%$ of scores and $55 \%-70 \%$ of coverage) work flows (Protocols ${ }^{\circ} \mathrm{A}^{\circ}{ }^{\circ}$ and $^{\circ} \mathrm{A} 2,{ }^{\circ}$ Table $^{\circ} 1$ )..$^{\circ}$ This $^{\circ}{ }^{\circ} s^{\circ}$ consistent $^{\circ}$ with the ${ }^{\circ}$ results $^{\circ}$ obtained $^{\circ}$ by $^{\circ} \mathrm{Chen}^{\circ}[32],{ }^{\circ}$ who $^{\circ}$ reported $^{\circ}$ the identification of $10 \mathrm{ng}$ of single proteins (phosphorylase B at $\sim 69 \mathrm{fmol} / \mu \mathrm{L}, \mathrm{BSA}$ at $\sim 97 \mathrm{fmol} / \mu \mathrm{L}$, and ADH at $\sim 180 \mathrm{fmol} / \mu \mathrm{L}$ ) in a 4 min experiment (1 s survey and $-\mathrm{s}$ MS/MS scan times) using direct infusion. However, using CB-ESI with a 12.5 min experiment (10 s survey and -s MS/MS scan times), cytochrome $c(50 \mathrm{fmol} / \mu \mathrm{L})$ was identified at both concentrations with MOWSE scores and coverage similar to those obtained with the LC-12 work flow (up to $88 \%$ and $145 \%$, respectively) and with the LC-isocratic work flow (49\% and $84 \%$, respectively) (data not shown). CB-ESI analyses also had a low coefficient of variation $(<10 \%$ ) (data not shown). Identification by CB-ESI-MS/MS was also possible with shorter (10.6 min) and longer (30.4, 31.2, and $33 \mathrm{~min}$ ) experiments by compromising reproducibility and throughput, respectively (data not shown).

Six-protein mixture study. Results of a CB-ESI analysis of the more complex six-protein mixture revealed a lack of positive detection for low protein concentration samples $(\leq 50 \mathrm{fmol} / \mu \mathrm{L})$ if survey and MS/MS scan times were short ( $<5 \mathrm{~s}$ and $<3 \mathrm{~s}$, respectively), especially for cytochrome $c$ and $\beta$-galactosidase (data not shown). Several trends that were observed for single protein analysis were again observed in the analysis of the protein mixture, including: (1) no major improvement of score and coverage for survey scan times beyond $3 \mathrm{~s}$; (2) increased scores and coverage with increasing MS/MS scan time for highly abundant proteins (BSA and apo-transferrin); (3) variability when few peptides per protein are detected, as was the case for cytochrome $c$, lysozyme, $\mathrm{ADH}$, and $\beta$-galactosidase. It is noteworthy that $\mathrm{ADH}$ and $\beta$-galactosidase produced lower scores and coverage than the other proteins with the LC-12 and LC-isocratic work flows, as well as with the CB-ESI work flow.

All six proteins in the 50 and $500 \mathrm{fmol} / \mu \mathrm{L}$ concentration mixtures were identified with the 10.6, 12.5, 31.2, and 33 min protocols. No identification was possible for shorter experiment times ( 3.3 to $6.6 \mathrm{~min}$ ) in the case of cytochrome $c$ (unlike the single protein case), lysozyme, and $\beta$-galactosidase (data not shown). The $12.5 \mathrm{~min}$ (10 $\mathrm{s}$ survey and $3 \mathrm{~s}$ MS/MS scans) experiment allowed 
(a)

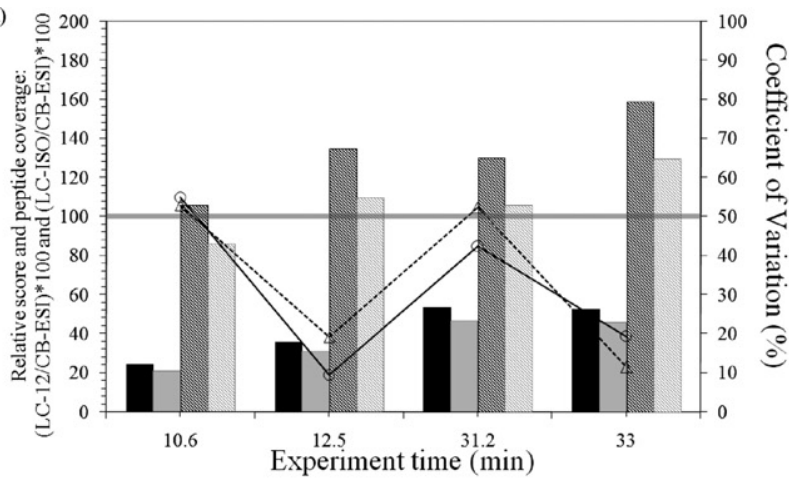

(b)

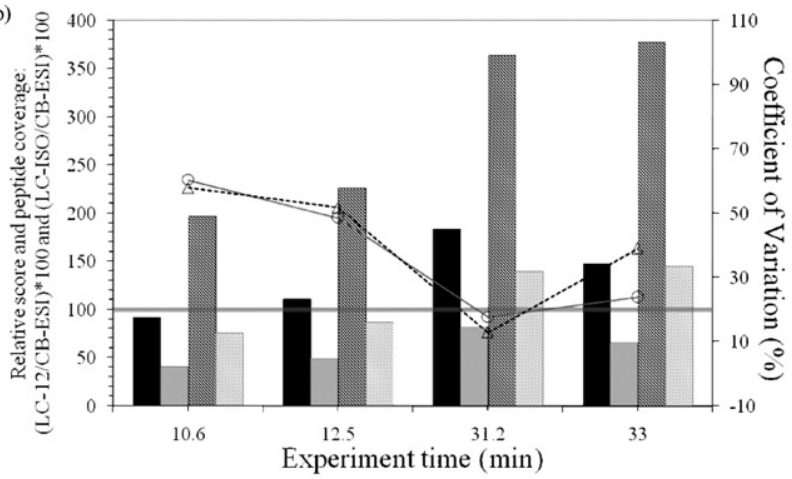

(c)

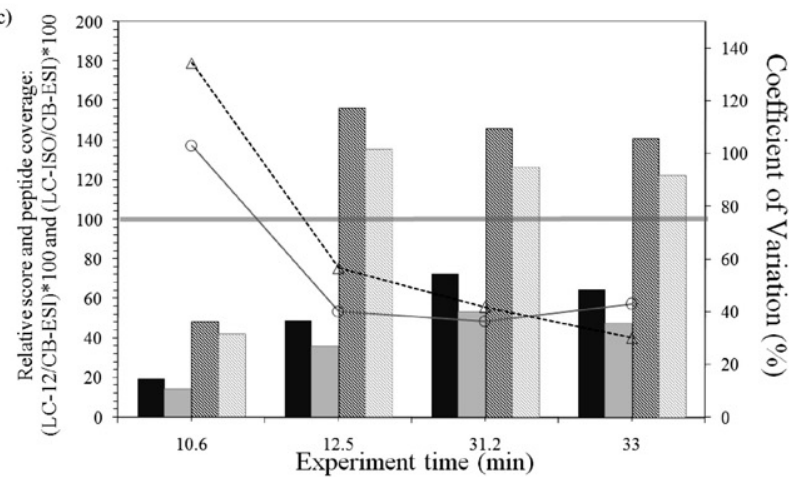

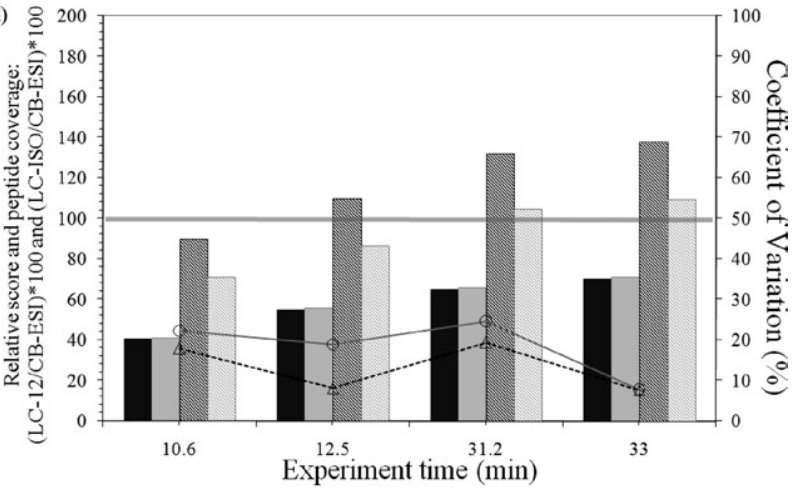

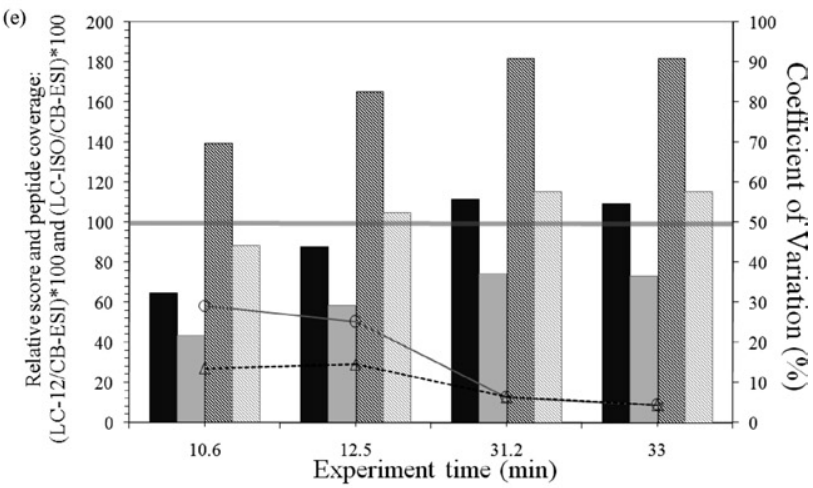

(1)

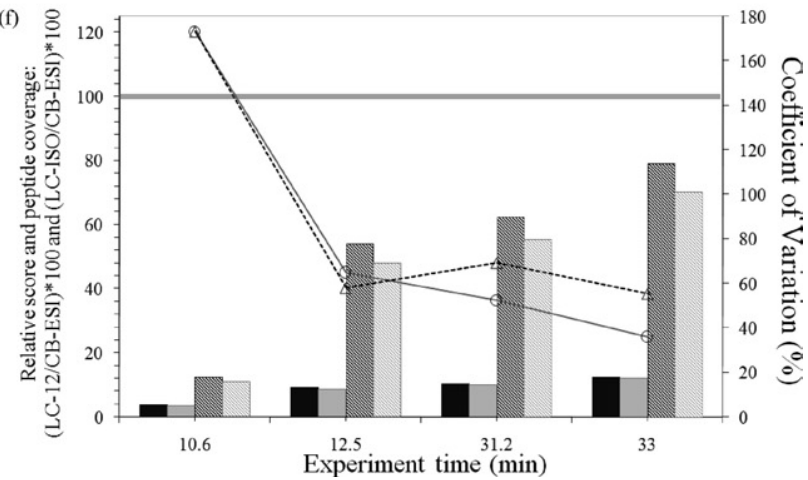

Figure 6. Relative comparison of CB-ESI to LC-ESI results for $500 \mathrm{fmol} / \mu \mathrm{L}$ of: (a) cytochrome $c$; (b) lysozyme; (c) ADH; (d) BSA; (e) apo-transferrin; (f) $\beta$-galactosidase. No relative agreement of the results for ADH from CB-ESI to the LC-isocratic is shown, because it did not yield an identification for

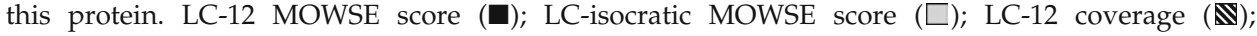
LC-isocratic coverage $(\mathbb{\mathbb { Q }})$; coefficient of variance of MOWSE score $(\bigcirc)$; coefficient of variance of coverage $(\triangle)$.

identification of all proteins, and was determined to be the optimal IDA protocol for the CB-ESI device. Use of this protocol produced similar or higher MOWSE scores to those obtained from the LC-12 work flow (36\% to $111 \%$ of the HPLC-ESI results), coupled with higher levels of peptide coverage (110\% to $227 \%$ of HPLC-ESI results) for five out of the six proteins at both concentrations ${ }^{\circ}\left(\right.$ Figure $\left.^{\circ} 6\right){ }^{\circ} \beta$-Galactosidase, ${ }^{\circ}$ although ${ }^{\circ}$ positively identified, had the lowest relative results to those obtained with the LC-12 work flow (9\% and 54\% of MOWSE score and peptide coverage of HPLC-ESI results). Positive protein identification was still possible with the 12.5 min CB-ESI protocol, even though the results were generally lower than those from the LC- isocratic work flow (MOWSE scores 9\% to 59\% of HPLC-ESI; peptide coverage $48 \%$ to $136 \%$ of HPLC-ESI)

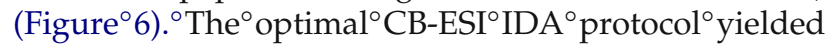
MOWSE scores and coverage with coefficients of variation of $0 \%$ to $65 \%$, and in less time than either of the HPLC-ESI $^{\circ}$ work $^{\circ}$ flow $^{\circ}$ analyses $^{\circ}\left(25^{\circ} \text { min }\right)^{\circ}\left(\right.$ Figure $\left.^{\circ} 6\right)$. Significant scores and coverage were found after 11 cycles, which means an increase in throughput of $\sim 4$-fold compared with the LC-isocratic work flow. It was also possible to identify all the proteins in less time (10.6 min) by slightly compromising the MOWSE score criterion. Although the 33 min CB-ESI experiment may have outperformed the LC-isocratic experiments with regard to improved MOWSE score and coverage, it 
exceeded the 25 min length of the HPLC-ESI experiments. Generally, the comparisons of score and coverage results from the CB-ESI analyses of the $50 \mathrm{fmol} / \mu \mathrm{L}$ concentration samples were similar in percentage terms to those obtained from the $500 \mathrm{fmol} / \mu \mathrm{L}$ samples (data not shown). Overall, peptide coverage percentage was found to be greater with the use of CB-ESI (and the optimal protocol) relative to the use of HPLC-ESI, consistent with the results of a previous study in which a chip-based infusion analysis of off-line capillary LC fractions yielded a higher sequence coverage than online capillary LC-MS/MS for $500 \mathrm{fmol}$ BSA and fourprotein $^{\circ}$ digests $^{\circ}[40]$.

\section{Peptide Identifications per Cycle in CB-ESI-MS/MS}

The number of positive peptide identifications from the single protein and six-protein mixture per cycle was determined to analyze the efficiency of the 10.6, 12.5 , and $33 \mathrm{~min}$ protocols described in the previous section. The results indicate that the number of additional unique positive peptide identifications yielded per MS/MS scan declines with increasing MS/MS scan number (data not shown). In this study, significant peptide identifications were obtained after 11 cycles. For the 12.5 (optimal) and 10.6 min experiments, the total numbers of unique successful MS/MS scans (i.e., those that found a new peptide) represent only $31 \%$ to $37 \%$ and $6 \%$ to $9 \%$ of the total MS/MS performed (198 scans) for the protein mixture and cytochrome $c$, respectively. For cytochrome $c$ alone, most of the successful identification increments occurred in the first six cycles. For the sixprotein mixture, on the other hand, it was still possible to obtain new identifications up to cycle 16, due to the greater variety of peptides in the mixture.

\section{Implications of Database Selection}

A comparison between the scores and peptide coverage percentage given (from all the protocols) by Mascot using two different databases (MSDB and NCBInr) revealed that no difference was found in the score and coverage in $95 \%$ of the cases. In the remaining $5 \%$, the MOWSE score and peptide coverage were higher when the MSDB database was used (data not shown). In some cases, the use of an organism-specific database was required to identify peptides from $\mathrm{ADH}(18 \%$ of all cases) and $\beta$-galactosidase ( $44 \%$ of all cases). In $\sim 50 \%$ of all cases, there was an increase in the MOWSE score and protein coverage obtained by changing from a general database search to a specific organism database search for both these proteins (data not shown). This phenomenon was particularly pronounced for $\beta$-galactosidase. The reasons for this are not clear and this observation is the subject of future investigation.

\section{Conclusions}

A rapid, sensitive, and reproducible CB-ESI method for the identification of proteins from a complex mixture has been described for use of the Advion NanoMate HD with the Applied Biosystems QStarXL, based on the systematic study of the major IDA parameters and sample preparation options. Although the actual IDA parameters will vary somewhat for other instrumentation, we expect our findings to be generally applicable.

These results demonstrate that the automated CBESI system is a valuable tool in high-throughput protein identification for single-protein samples (gel spots) and a viable alternative for the rapid protein identification of shotgun fractions (employing in-solution digestion). This is because infusion requires less overall MS analysis time and eliminates the need for spray optimization over a range of solvent compositions, as is required for the HPLC-ESI. Our results confirm those obtained by $^{\circ} \mathrm{Zhang}^{\circ} \mathrm{et}^{\circ}{ }^{\circ} \mathrm{ol}^{\circ}[39]^{\circ},{ }^{\circ} \mathrm{in}^{\circ}$ which $^{\circ} 38^{\circ}$ out $^{\circ}$ of $^{\circ} 50^{\circ} \mathrm{E}$. coli gel spots (one protein from each spot) were unambiguously identified in $3.5 \mathrm{~min}$ analyses, and provide substantially more benchmarking information with respect to optimizing analysis times and sample preparation techniques for the rapid identification of proteins in more complex mixtures. We envision that infusion electrospray can form part of a complex shotgun proteomic work flow preceded by upstream off-line fractionation employing either LC-based methods or by other shotgun methods such as gel-fractionation or IEF, as the CB-ESI work flow yielded greater peptide coverage employing considerably less sample and provided positive protein identifications in less time compared with either the isocratic or gradient HPLC-ESI work flows.

The $^{\circ}$ results $^{\circ}$ presented $^{\circ}$ here $^{\circ}$ and $^{\circ}$ elsewhere $^{\circ}\left[32,{ }^{\circ} 41\right]$ suggest that the CB-ESI work flow is complementary to an online HPLC-ESI work flow, as the latter is more likely to identify less abundant peptides that might be suppressed by highly abundant peptides, due to on-column sample concentration. Further studies should include the optimization of the CB-ESI device for protein quantification and the identification of post-translational modifications.

\section{Acknowledgments}

The authors thank the University of Sheffield's Ph.D. Scholarship Program and the United Kingdom's Engineering and Physical Science Research Council (EPSRC) for funding (grant GR/S84347/ 01), for an Advanced Research Fellowship for PCW (grant GR/ A11311/01), and a visiting professorship for KFR (grant GR/ S82800/01). They acknowledge M. Barrios-Llerena and C. S. Gan for their expertise and technical support, and also thank Dr. Mark Dickman for critical comments.

\section{References}

1. Peng, J.; Gygi, S. P. Proteomics: The Move to Mixtures. J. Mass Spectrom. 2001, 36, 1083-1091.

2. Anderson, L.; Seilhamer, J. A Comparison of Selected mRNA and Protein Abundances in Human Liver. Electrophoresis 1997, 18, 533-537. 
3. Gygi, S. P.; Rochon, Y.; Franza, B. R.; Aebersold, R. Correlation Between Protein and mRNA Abundance in Yeast. Mol. Cell. Biol. 1999, 19, 1720-1730.

4. Rappsilber, J.; Mann, M. What Does It Mean to Identify a Protein in Proteomics? Trends Biochem. Sci. 2002, 27, 74.

5. Ethier, M.; Hou, W.; Duewel, H. S.; Figeys, D. The Proteomic Reactor: A Microfluidic Device for Processing Minute Amounts of Protein Prior to Mass Spectrometry Analysis. J. Proteome Res. 2006, 5, 2754-2759.

6. Limbach, P. A.; Meng, Z. Integrating Micromachined Devices with Modern Mass Spectrometry. Analyst 2002, 127, 693-700.

7. Spikmans, V.; Lane, S. J.; Leavens, B.; Manz, A.; Smith, N. W. On-Line On-Chip Postcolumn Derivatization Reactions for Preionization of Analytes and Cluster Analysis in Gradient $\mu$-Liquid Chromatography/ Electrospray Mass Spectrometry. Rapid Commun. Mass Spectrom. 2002, 16, 1377-1388.

8. Thongboonkerd, V.; Songtawee, N.; Sritippayawan, S. Urinary Proteome Profiling Using Microfluidic Technology on a Chip. J. Proteome Res. 2007, 6, 2011-2018

9. Zhang, S.; Van Pelt, C. K. Chip-Based Nanoelectrospray Mass Spectrometry for Protein Characterization. Exp. Rev. Proteomics 2004, 1, $449-468$.

10. Gygi, S. P.; Han, D. K. M.; Gingras, A.-C.; Sonenberg, N.; Aebersold, R. Protein Analysis by Mass Spectrometry and Sequence Database Searching: Tools for Cancer Research in the Postgenomic Era. Electrophoresis 1999, 20, 310-319.

11. Gygi, S. P.; Aebersold, R. Mass Spectrometry and Proteomics. Curr. Opin. Chem. Biol. 2000, 4; 489 .

12. Aebersold, R.; Goodlett, D. R. Mass Spectrometry in Proteomics. Chem. Rev. 2001, 101, 269-296.

13. Celis, J. E.; Gromov, P. Two Dimensional Protein Electrophoresis: Can It Be Perfected? Curr. Opin. Biotechnol. 1999, 10, 16.

14. Gygi, S. P.; Corthals, G. L.; Zhang, Y.; Rochon, Y.; Aebersold, R. Evaluation of Two-Dimensional Gel Electrophoresis-Based Proteome Analysis Technology. PNAS 2000, 97, 9390-9395.

15. Dhingra, V.; Gupta, M.; Andacht, T.; Fu, Z. F. New Frontiers in Proteomics Research: A Perspective. Int. J. Pharm. 2005, 299, 1.

16. Breci, L.; Hattrup, E.; Keeler, M.; Letarte, J.; Johnson, R.; Haynes, P. A. Comprehensive Proteomics in Yeast Using Chromatographic Fractionation, Gas Phase Fractionation, Protein Gel Electrophoresis, and Isoelectric Focusing. Proteomics 2005, 5, 2018-2028

17. Issaq, H. J.; Conrads, T. P.; Janini, G. M.; Veenstra, T. D. Methods for Fractionation, Separation, and Profiling of Proteins and Peptides. Electrophoresis 2002, 23, 3048-3061.

18. Xiao, Z.; Conrads, T. P.; Lucas, D. A.; Janini, G. M.; Schaefer, C. F.; Buetow, K. H.; Issaq, H. J.; Veenstra, T. D. Direct Ampholyte-Free Liquid-Phase Isoelectric Peptide Focusing: Application to the Human Serum Proteome. Electrophoresis 2004, 25, 128-133.

19. Krijgsveld, J.; Gauci, S.; Dormeyer, W.; Heck, A. J. R. In-Gel Isoelectric Focusing of Peptides as a Tool for Improved Protein Identification. J. Proteome Res. 2006, 5(7):1721-1730

20. Gan, C. S.; Reardon, K. F.; Wright, P. C. Comparison of Protein and Peptide Prefractionation Methods for the Shotgun Proteomic Analysis of Synechocystis sp. PCC 6803. Proteomics 2005, 5, 2468-2478.

21. Chong, P. K.; Wright, P. C. Identification and Characterization of the Sulfolobus solfataricus P2 Proteome. J. Proteome Res. 2005, 4, 1789-1798.

22. Wilm, M.; Mann, M. Analytical Properties of the Nanoelectrospray Ion Source. Anal. Chem. 1996, 68, 1-8.

23. Steen, H.; Mann, M. The ABC's (and XYZ's) of Peptide Sequencing. Nat. Rev. Mol. Cell. Biol. 2004, 5, 699.

24. Mann, M.; Wilm, M. Error-Tolerant Identification of Peptides in Sequence Databases by Peptide Sequence Tags. Anal. Chem. 1994, 66, 4390-4399.

25. Shevchenko, A.; Wilm, M.; Vorm, O.; Mann, M. Mass Spectrometric Sequencing of Proteins from Silver-Stained Polyacrylamide Gels. Anal. Chem. 1996, 68, 850-858.

26. Ito, S.; Yoshioka, S.; Ogata, I.; Takeda, A.; Yamashita, E.; Deguchi, K. Nanoflow Gradient Generator for Capillary High-Performance Liquid
Chromatography-Nanoelectrospray Mass Spectrometry. J. Chromatogr. A 2004, 1051, 19 .

27. Xiang, R.; Shi, Y.; Dillon, D. A.; Negin, B.; Horvath, C.; Wilkins, J. A. Two-Dimensional LC/MS Analysis of Membrane Proteins from Breast Cancer Cell Lines MCF7 and BT474. J. Proteome Res. 2004, 3, 1278-1283.

28. Ihling, C.; Sinz, A. Proteome Analysis of Escherichia coli Using HighPerformance Liquid Chromatography and Fourier Transform Ion Cyclotron Resonance Mass Spectrometry. Proteomics 2005, 5, 2029-2042.

29. Wilm, M.; Shevchenko, A.; Houthaeve, T.; Breit, S; Schweigerer, L.; Fotsis, T.; Mann, M. Femtomole sequencing of proteins from polyacrylamide gels by nano-electrospray mass spectrometry. Nature 1996, 379466 .

30. Erdjument-Bromage, H.; Lui, M.; Lacomis, L.; Grewal, A.; Annan, R. S.; McNulty, D. E.; Carr, S. A.; Tempst, P. Examination of Micro-Tip Reversed-Phase Liquid Chromatographic extraction of peptide pools for mass spectrometric analysis. J. Chromatogr. A 1998, 826, 167.

31. Schmidt, A.; Karas, M.; Dulcks, T. Effect of Different Solution Flow Rates on Analyte Ion Signals in Nano-ESI MS, or: When Does ESI Turn Into Nano-ESI? J. Am. Soc. Mass Spectrom. 2003, 14, 492.

32. Chen, S. Rapid Protein Identification Using Direct Infusion Nanoelectrospray Ionization Mass Spectrometry. Proteomics 2006, 6, 16-25.

33. Zhang, B.; Liu, H.; Karger, B. L.; Foret, F. Microfabricated Devices for Capillary Electrophoresis-Electrospray Mass Spectrometry. Anal. Chem. 1999, 71, 3258-3264.

34. Deng, Y.; Zhang, H.; Henion, J. Chip-Based Quantitative Capillary Electrophoresis/Mass Spectrometry Determination of Drugs in Human Plasma. Anal. Chem. 2001, 73, 1432-1439.

35. Li, J.; LeRiche, T.; Tremblay, T.-L.; Wang, C.; Bonneil, E.; Harrison, D. J.; Thibault, P. Application of Microfluidic Devices to Proteomics Research: Identification of Trace-level Protein Digests and Affinity Capture of Target Peptides. Mol. Cell. Proteom. 2002, 1, 157-168.

36. Tan, A.; Benetton, S. Henion, J. D. Chip-Based Solid-Phase Extraction Pretreatment for Direct Electrospray Mass Spectrometry Analysis Using an Array of Monolithic Columns in a Polymeric Substrate. Anal. Chem 2003, 75, 5504-5511.

37. Moon, J. E.; Davis, T. J.; Galvin, G. J.; Schultz, G. A.; Corso, T. N.; Lowes, S. Integrated Monolithic Microfabricated Electrospray Device for Mass Spectrometry. 2000, Patent no. US656311.

38. Van Pelt, C. K.; Zhang, S.; Henion, J. D. Characterization of a Fully Automated Nanoelectrospray System with Mass Spectrometric Detection for Proteomic Analyses. J. Biomol. Tech. 2002, 13, 72-84.

39. Zhang, S.; Van Pelt, C. K.; Henion, J. D. Automated Chip-Based Nanoelectrospray-Mass Spectrometry for Rapid Identification of Proteins Separated by Two-Dimensional Gel Electrophoresis. Electrophoresis 2003, 24, 3620-3632.

40. Van Pelt, C. K.; Zhang, S.; Howe, K. J. Automated Nanoelectrospray Mass Spectrometry Analysis of Off-Line Collected Liquid Chromatography Fractions: A Powerful New Technique for Increasing Sequence Coverage. Proceedings of the 51st ASMS Conference in Mass Spectrometry and Allied Topics; June 2003, Montreal, Canada.

41. Lund, A. L.; Van Pelt, C. K.; Nold, M. J.; Martin, L. B.; Li, J. B. Comparison of Peak Parking versus Automated Fraction Analysis of a Complex Protein Mixture. Proceedings of the 51st ASMS Conference in Mass Spectrometry and Allied Topics; June 2003, Montreal, Canada.

42. Wickremsinhe, E. R.; Ackermann, B. L.; Chaudhary, A. K. Validating Regulatory-Compliant Wide Dynamic Range Bioanalytical Assays Using Chip-Based Nanoelectrospray Tandem Mass Spectrometry. Rapid Commun. Mass Spectrom. 2005, 19, 47-56.

43. Pappin, D. J.; Hojrup, P.; Bleasby, A. J. Rapid Identification of Proteins by Peptide-Mass Fingerprinting. Curr. Biol. 1993, 3, 327-332.

44. Perkins, D. N.; Pappin, D. J. C.; Creasy, D. M.; Cottrell, J. S. ProbabilityBased Protein Identification by Searching Sequence Databases Using Mass Spectrometry data. Electrophoresis 1999, 20, 3551-3567.

45. Sterner, J. L.; Johnston, M. V.; Nicol, G. R.; Ridge, D. P. Signal Suppression in Electrospray Ionization Fourier Transform Mass Spectrometry of Multicomponent Samples. J. Mass Spectrom. 2000, 35, 385-391. 